\title{
Analysis of polymorphisms in codons 11,72 and 248 of TP53 in Brazilian women with breast cancer
}

\author{
B.C. Almeida ${ }^{1}$, J.P.F.O. Kleine ${ }^{1}$, C.M. Camargo-Kosugi ${ }^{1,2}$, M.R. Lisboa ${ }^{1}$, \\ C.N. França ${ }^{3}$, J.P. França ${ }^{4}$ and I.D.C.G. Silva ${ }^{1}$ \\ 'Laboratório de Ginecologia Molecular e Proteômica, Departamento de Ginecologia, \\ Universidade Federal de São Paulo, São Paulo, SP, Brasil \\ ${ }^{2}$ Centro de Pesquisa Translacional, \\ Departamento de Otorrinolaringologia e Cirurgia de Cabeça e Pescoço, \\ Universidade Federal de São Paulo, São Paulo, SP, Brasil \\ ${ }^{3}$ Departamento de Lípides, Aterosclerose e Biologia Vascular, \\ Universidade Federal de São Paulo, São Paulo, SP, Brasil \\ ${ }^{4}$ Laboratório de Biofísica Celular e Molecular, Departamento de Ciências Biológicas, \\ Universidade Estadual de Santa Cruz, Ilhéus, BA, Brasil \\ Corresponding author: B.C. Almeida \\ E-mail: bruc_10@hotmail.com \\ Genet. Mol. Res. 15 (1): gmr.15017055 \\ Received June 23, 2015 \\ Accepted October 26, 2015 \\ Published February 19, 2016 \\ DOI http://dx.doi.org/10.4238/gmr.15017055
}

ABSTRACT. The association between TP53 gene polymorphisms and breast cancer $(\mathrm{BC})$ in Brazilian women is a controversial topic. In this cross-sectional study, we evaluated the association between clinical pathological variables and three polymorphisms (TP53*11, TP53*72, and TP53*248) in BC patients and controls. Genomic DNA was extracted from the blood cells of 393 participants; the cancer-free control subjects were 26-72 years old ( $41 \pm 11.03$ ) and the BC patients were $28-80$ years old (51 \pm 10.70 ). We used standard polymerase chain reaction-restriction fragment length polymorphism and confirmed the results by genetic sequencing. In TP53 ${ }^{*} 11$, there was $100 \%$ homozygous Glu distribution in both groups. 
TP53*72 showed genotypic distribution: in the control group, there was $16.10 \%$ homozygous Pro, and $42.44 \%$ heterozygous and $41.46 \%$ homozygous Arg; in the BC group, there was $15.43 \%$ homozygous Pro, and $42.55 \%$ heterozygous and $42.02 \%$ homozygous Arg. The relative frequency of each allele was $0.37 \%$ for Pro and $0.63 \%$ for Arg in the control group, and $0.37 \%$ for Pro and $0.63 \%$ for Arg in the BC group. The nuclear grade $(P=0.0084)$ and adapted histological grade $(P=0.0265)$ were associated with TP53*72. The distribution of the codon 72 genotypes did not deviate from Hardy-Weinberg equilibrium in either group. In TP53*248, there was $100 \%$ homozygous Arg distribution in both groups. In codon 72 , the Arg allele is the most prevalent in Brazilian women. TP53*72 may be associated with susceptibility to $\mathrm{BC}$, although more studies are required to evaluate the profile of Brazilian women with $\mathrm{BC}$.

Key words: Breast cancer; Restriction enzymes; TP53; p53 protein; SNP; Brazilian women

\section{INTRODUCTION}

Breast cancer $(\mathrm{BC})$ is a non-cutaneous, multifactorial, heterogeneous disease. It has many subtypes with distinct biological features that are driven by numerous underlying molecular alterations, and can exhibit different potentials for recurrence and distant metastasis (Yersal and Barutca, 2014). Mutations of the TP53 gene are the most common genetic alterations in BC, accounting for $30 \%$ of the cases. However, some of the molecular subtypes of BC have higher levels of alteration. Some types of alteration are clearly linked to higher frequency of substitutions, resulting in the production of p53 protein with potential new functions, such as p63 and p73 inactivation. Notably, molecular apocrine and basal-like tumors present a much higher frequency of complex mutations (deletions/ insertions) that often lead to a lack of p53 protein (Bertheau et al., 2013).

The 553 protein plays an important role in cell-cycle regulation and maintenance of genome stability by preventing mutations (Stojnev et al., 2010), and the most prominent property of p53 as a protein is its action as a transcription factor (Levine and Oren, 2009). The response to stress occurs through the induction of $\mathrm{p} 53$, which essentially happens by post-translational modifications resulting in protein stabilization (by escape from proteasome-mediated degradation), and in conformational changes that increase the affinity of p53 for specific DNA sequences. This pathway regulates the transcription of target genes or interacts with heterologous factors to mediate negative regulation of cell-cycle progression and induction of apoptosis. Cell-cycle arrest is controlled by transcriptional modulation of p53-transactivated genes such as CDKN1A and GADD45. Induction of apoptosis involves both transcription-dependent and -independent mechanisms. Pro-apoptotic transcriptional targets of p53 include PUMA, BAX, and FAS/CD95 (Méplan et al., 2000; de Moura Gallo et al., 2005). p53 also interacts with numerous cellular proteins, and these molecular interaction might contribute to the inhibitory role of p53 in tumorigenesis (Whibley et al., 2009).

TP53 mutations are found in all exons of the gene, but the mutation located at codon 11 in exon 2, which encodes the extreme $\mathrm{N}$-terminus, and the mutation of the last codon of exon 11, which encodes the extreme C-terminus, account for only $0.1 \%$ of the 15,000 mutations identified. These regions contain important regulatory domains and sites of post-translational modification, which 
play an important role in the control of p53 activity. The N-terminus of p53 contains the binding site for $\mathrm{mdm} 2$, the main regulator of $\mathrm{p} 53$ protein stability, and the $\mathrm{C}$-terminus participates in the regulation of DNA-binding activity (Guimaraes and Hainaut, 2002). The critical region, in which many mutations are recognized, is called the "hotspot"; it has six codons and is detectable in almost all types of cancer (Stojnev et al., 2010). These residues are all located at the DNA-binding surface of the protein and play important roles either in protein-DNA contacts (codons 245, 248, and 273) or in the conformation of the protein (codons 175, 249, and 282) (Guimaraes and Hainaut, 2002; Stojnev et al., 2010). The most widely studied polymorphism in exon 4 is an amino acid residue change, proline/arginine (Pro/ Arg), on the reverse strand located at codon 72 . The prevalence of the Arg allele ranges from 40 to $80 \%$ in tumors (Pim and Banks, 2004). Several studies suggest that the polymorphism described above may have a functional impact. Moreover, it has been shown that the Arg and Pro p53 variants have different half-lives and transcriptional properties in vitro. Nevertheless, some researchers have suggested the possibility that the presence of the Arg allele might be linked with a higher susceptibility to cancers associated with human papillomavirus infections (Guimaraes and Hainaut, 2002;Akkiprik et al., 2009), and other cancer types such as lung, hepatocellular, colorectal, and bladder cancer. We used clinical pathological feature analysis to investigate the polymorphisms at codons 11,72 , and 248 by comparing women with $\mathrm{BC}$ with healthy women. The analysis of these three polymorphisms may be relevant to the development of $\mathrm{BC}$ once the mutations have occurred at important sites of the TP53 gene. Moreover, identifications of these polymorphisms may be useful for predicting clinical variables in the relatives of the $\mathrm{BC}$ patient.

\section{MATERIAL AND METHODS}

\section{Study population}

The Research Ethics Committee of Universidade Federal de São Paulo UNIFESP/EPM under protocol No. 72.537 approved this study. Prior to commencement, all participants signed an informed consent form. This cross-sectional study included 188 women in whom BC had been surgically and histopathologically confirmed; there were $169(89.89 \%)$ cases of invasive ductal carcinoma, nine cases of invasive lobular carcinoma (4.79\%), five cases of in situ ductal carcinoma (2.66\%); and five cases $(2.66 \%)$ were not recognized.

Two hundred and five women with no previous history of cancer were assigned to a nonmalignant control group. All the women came from the same population, ethnicity, and geographic region.

\section{Genotype assay}

Genomic DNA was extracted from the lymphocytes in peripheral blood samples using an Illustra ${ }^{\mathrm{TM}}$ blood genomicPrep Spin Kit (GE Healthcare, Piscataway, NJ, USA) according to the manufacturer instructions. The polymerase chain reaction-restriction fragment length polymorphism (PCR-RFLP) conditions used to amplify the fragments containing the TP53 codons 11 (rs201382018), 72 (rs1042522), and 248 (rs11540652) have been described previously (Camargo-Kosugi et al., 2014), and were adapted in our laboratory.

Briefly, each PCR mixture $(25 \mu \mathrm{L})$ contained $25 \mathrm{pM}$ each primer, Polymerase Chain Reaction Master Mix - Taq DNA polymerase (pH 8.5), dATP, dGTP, dCTP, dTTP and $\mathrm{MgCl}_{2}$ 
(Promega, Madison, WI, USA), and 50-100 ng genomic DNA, and the volume was completed with Nuclease-Free Water (Promega). The primers amplified fragments of 379 base pairs (bp) in the TP53*11 codon, 279 bp in the TP53*72 codon (Figure 1), and 236 bp in the TP53*248 codon. The amplified PCR samples were analyzed on $2 \%$ agarose gel using ethidium bromide staining, followed by treatment of the amplified fragment with an appropriate restriction enzyme. The amplicons of TP53*11, TP53*72, and TP53*248 were digested with Taq ${ }^{\alpha}$ I, BstUI, and Hpall restriction enzymes (New England BioLabs, Ipswich, MA, USA), respectively. Because the presence or absence of the restriction enzyme recognition site results in the formation of restriction fragments of different sizes, allele identification was achieved by $3 \%$ agarose gel electrophoresis analysis (Amersham Pharmacia Biotech model EPS1001, Piscataway, NJ, USA), observation was carried out under UV light, and the images were recorded using a Kodak Digital Science 1D system. The PCR conditions, primer sequences, enzyme digestion temperatures and durations, fragment sizes, and amino acid changes are described in Table 1.

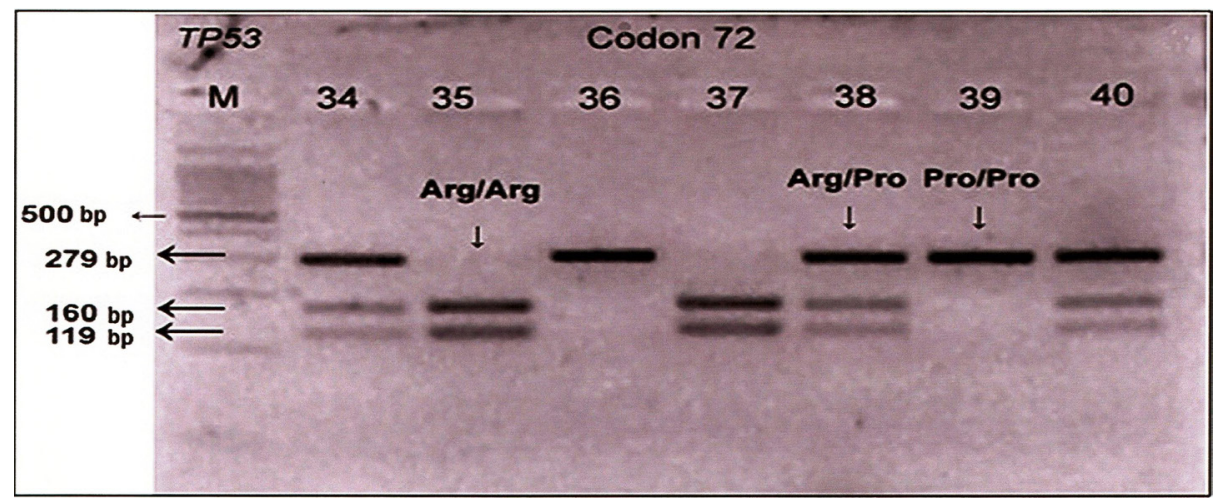

Figure 1. Polymerase chain reaction-restriction fragment length polymorphism (PCR-RFLP) in codon 72 polymorphism detection of homozygous Pro (Pro/Pro), heterozygous (Pro/Arg), and homozygous Arg (Arg/Arg). Lane M = 100-bp ladder.

Table 1. Primers, restriction enzymes, and polymerase chain reaction (PCR) conditions.

\begin{tabular}{|c|c|c|c|c|c|}
\hline Polymorphism (locations) & Primers sequences $\left(5^{\prime} \rightarrow 3^{\prime}\right)$ & Restriction enzyme & SNP sequences & Amino acid & DNA fragments \\
\hline $\begin{array}{l}\text { TP53*11 } \\
T 201382018\end{array}$ & $\begin{array}{l}\text { F: 5'-CTTGGGTTGTGGTGAAACATTG-3' } \\
\text { R: 5'-AGCGAAAATTCATGGGACTGAC-3' }\end{array}$ & 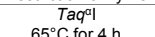 & GAG & Glu & $239+140$ \\
\hline$T P 53^{*} 72^{*}$ & $\begin{array}{l}\text { R: 5'-AGCGAAAAI ICAIGGGACTGAC-3' } \\
\text { F: 5'-TCCCCCTTGCCGTCCCAA-3' }\end{array}$ & Bstul & CCC & Pro & 279 \\
\hline$\frac{\text { rs } 1042522}{T P 53^{\star} 248}$ & R: 5'-CGTGCAAGTCACAGACTT-3' & $\frac{60^{\circ} \mathrm{C} \text { for } 4 \mathrm{~h}}{\text { Hpall }}$ & $\begin{array}{l}\text { CGC } \\
\text { CGG }\end{array}$ & $\frac{\text { Arg }}{\text { Arg }}$ & $\frac{160+119}{164+72}$ \\
\hline rs11540652 & 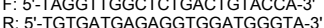 & $37^{\circ} \mathrm{C}$ for $4 \mathrm{~h}$ & CAG & $\mathrm{Gln}$ & 236 \\
\hline \multicolumn{6}{|l|}{ PCR conditions } \\
\hline Initial denaturations $\left({ }^{\circ} \mathrm{C} / \mathrm{m}\right.$ & Denaturing $\left({ }^{\circ} \mathrm{C} / \mathrm{s}\right)$ & aling $\left({ }^{\circ} \mathrm{C} / \mathrm{s}\right)$ & Polymerization & & Final extension $\left({ }^{\circ} \mathrm{C} / \mathrm{min}\right)$ \\
\hline \multicolumn{2}{|l|}{$94 / 5$} & \multicolumn{3}{|c|}{40 cycles } & $72 / 7$ \\
\hline
\end{tabular}

*Three fragments with 279, 160, and 119 bp indicates heterozygous (Pro/Arg) SNP = single-nucleotide polymorphism.

\section{Direct sequencing of DNA fragment}

Direct sequencing of double-stranded DNA fragments was performed using an Applied Biosystems 3500/3500xL Genetic Analyzer (Applied Biosystems | Hitachi, Foster City, CA, USA), as shown in Figure 2. 


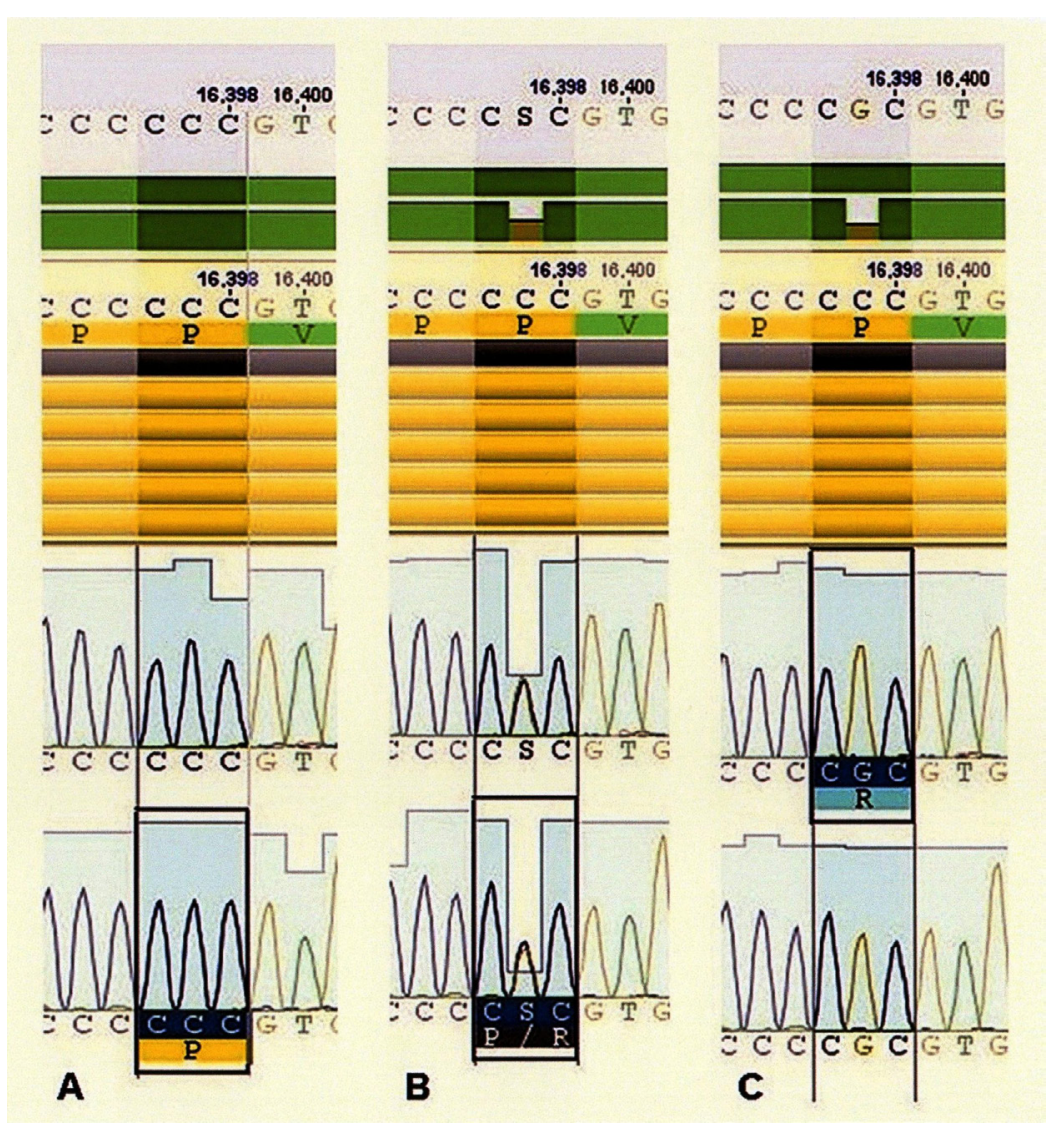

Figure 2. DNA sequencing of codon 72. A. Homozygous Pro. B. Heterozygous Pro/Arg. C. Homozygous Arg.

\section{Statistical analysis}

Analyses were performed using the SPSS (v20.0; Chicago, IL, USA) and the GraphPad Prism (v3.0; CA, USA) softwares. The $\chi^{2}$ test was used to analyze categorical variables and the two-sided unpaired Student $t$-test was used to compare the continuous variable age. The strength of association between each TP53 polymorphism and cancer risk was evaluated by pooled odds ratios with $95 \%$ confidence intervals. The association between independent variables and the development of breast cancer was determined using a logistic regression method. The association between the TP53 polymorphism and clinical pathological characteristics of the BC was assessed using the $\chi^{2}$ test. P-values less than 0.05 were considered statistically significant. Hardy-Weinberg equilibrium (HWE) was detected using a goodness-of-fit $\chi^{2}$ test.

\section{RESULTS}

The analysis included 393 women. The cancer-free control subjects were $26-72$ years old (mean age $41 \pm 11.03$ ) and the BC patients were $28-80$ years old (mean age $51 \pm 10.70$ ). These values were corrected by logistic regression $(P<0.0001)$. 
We did not detect TP53 codon 11 or 248 polymorphisms in either controls or cases using PCR-RFLP, and we did not find any genetic variations; all samples were homozygous Glu and homozygous Arg for the two codons, respectively. The distribution of the codon 72 genotypes in control and patient groups did not deviate from the HWE. Genotype proportions in the control and case groups are presented in Table 2, with no significant statistical association of the Pro/ Pro genotype with $B C$ risk $(P=0.9823)$. The relative frequency of each allele was $0.37 \%$ for Pro and $0.63 \%$ for Arg in the control group, and $0.37 \%$ for Pro and $0.63 \%$ for Arg in the BC group (P = 0.8584). The Arg allele was the most frequent in both groups and showed a higher percentage in more than half of the samples.

Table 2. Distribution of TP53*72 polymorphism genotypes among breast cancer and control groups.

\begin{tabular}{l|c|c|c|c|c|c|c|c}
\hline $\mathrm{N}(\%)$ & Pro/Pro & Pro/Arg & Arg/Arg & OR $^{\mathrm{a}}$ & $\mathrm{RR}$ & $95 \% \mathrm{Cl}$ & $\mathrm{P}^{*}$ \\
\cline { 1 - 5 } Control & 205 & $33(16.10)$ & $87(42.44)$ & $85(41.46)$ & 1.052 & 1.044 & 0.6108 to 1.812 & 0.9823 \\
\cline { 1 - 5 } & 188 & $29(15.43)$ & $80(42.55)$ & $79(42.02)$ & & & &
\end{tabular}

adapted odds ratio, Pro/Pro vs Arg/Pro and Arg/Arg; *P-value determined by $\chi^{2}$ test.

The clinical and pathological features of $T P 53^{*} 72$ in the BC patients were analyzed according to genotype, and the results are shown in Table 3; significant differences were observed in the nuclear grade $(P=0.0084)$. We also analyzed the adapted histological grade, i.e., grade I versus II and III, and a significant difference in the distribution was found between the genotypes for this variable $(P=0.0265)$.

\begin{tabular}{|c|c|c|c|c|c|c|c|c|c|}
\hline Variables & Pro/Pro & Pro/Arg & Arg/Arg & $\mathrm{P}^{*}$ & Variables & Pro/Pro & Pro/Arg & Arg/Arg & $\mathrm{P}^{*}$ \\
\hline \multicolumn{5}{|l|}{ Age, years } & \multicolumn{5}{|l|}{ HER2 status } \\
\hline$<35$ & $1(10)$ & $5(50)$ & $4(40)$ & \multirow[t]{5}{*}{0.7463} & Positive & $7(23.33)$ & $12(40)$ & $11(36.67)$ & \multirow[t]{3}{*}{0.2128} \\
\hline $35-39$ & $0(0)$ & $5(71.43)$ & $2(28.57)$ & & Negative & $22(14.19)$ & $68(43.87)$ & $65(41.94)$ & \\
\hline $40-49$ & $10(1612)$ & $26(41.94)$ & $26(41.94)$ & & Missing & $0(0)$ & $0(0)$ & $3(100)$ & \\
\hline $50-59$ & $11(16.92)$ & $23(35.39)$ & $31(47.69)$ & & \multicolumn{5}{|c|}{ Neoadjuvant chemotherapy response } \\
\hline$\geq 60$ & $7(15.91)$ & $21(47.73)$ & $16(36.36)$ & & No & $21(15.22)$ & $56(40.58)$ & $61(44.20)$ & \multirow[t]{4}{*}{0.7350} \\
\hline Tumor stag & & & & & RP $<50 \%$ & $2(9.52)$ & $11(52.38)$ & $8(38.10)$ & \\
\hline $\mathrm{TI}$ & $3(13.64)$ & $10(45.45)$ & $9(40.91)$ & \multirow[t]{6}{*}{0.5569} & $\mathrm{RP}>50 \%$ & $6(23.08)$ & $11(42.31)$ & $9(34.61)$ & \\
\hline TII & $12(15)$ & $28(35)$ & $40(50)$ & & Missing & $0(0)$ & $2(66.67)$ & $1(33.33)$ & \\
\hline T IIII & $13(17.33)$ & $36(48)$ & $26(34.67)$ & & \multicolumn{5}{|l|}{ Adjuvant chemotherapy } \\
\hline TIV & $0(0)$ & $5(62.50)$ & $3(37.50)$ & & Yes & $25(14.54)$ & $75(43.60)$ & $72(41.86)$ & \multirow[t]{3}{*}{0.6069} \\
\hline Missing & $1(33.33)$ & $1(33.33)$ & $1(33.33)$ & & No & $4(28.57)$ & $4(28.57)$ & $6(42.86)$ & \\
\hline \multicolumn{4}{|c|}{ Histological grade } & & Missing & $0(0)$ & $1(50)$ & $1(50)$ & \\
\hline 1 & $6(35.29)$ & $8(47.06)$ & $3(17.65)$ & \multirow[t]{4}{*}{0.0799} & \multicolumn{5}{|l|}{ Radiotherapy } \\
\hline II & $16(13.22)$ & $56(46.28)$ & $49(40.50)$ & & Yes & $24(16.78)$ & $63(44.06)$ & $56(39.16)$ & \multirow[t]{3}{*}{0.6562} \\
\hline III & $7(14.89)$ & $15(31.92)$ & $25(53.19)$ & & No & $5(11.63)$ & $16(37.21)$ & $22(51.16)$ & \\
\hline Missing & $0(0)$ & $1(33.33)$ & $2(66.67)$ & & Missing & $0(0)$ & $1(50)$ & $1(50)$ & \\
\hline \multicolumn{5}{|c|}{ Nuclear grade } & \multicolumn{5}{|l|}{ Hormonal therapy } \\
\hline 1 & $4(36.36)$ & $4(36.36)$ & $3(27.28)$ & \multirow[t]{4}{*}{0.0084} & Yes & $5(21.74)$ & $7(30.43)$ & $11(47.83)$ & \multirow[t]{3}{*}{0.5217} \\
\hline II & $16(13.01)$ & $63(51.22)$ & $44(35.77)$ & & No & $24(14.64)$ & $73(44.51)$ & $67(40.85)$ & \\
\hline III & $9(17.31)$ & $13(25)$ & $30(57.69)$ & & Missing & $0(0)$ & $0(0)$ & $1(100)$ & \\
\hline Missing & $0(0)$ & $0(0)$ & $2(100)$ & & \multicolumn{5}{|l|}{ Molecular subtype } \\
\hline \multicolumn{5}{|c|}{ Lymph nodes committed } & Luminal $\mathrm{A}$ & $14(15.39)$ & $45(49.45)$ & $32(35.16)$ & \multirow[t]{6}{*}{0.5019} \\
\hline $0 \leq 3$ & $22(17.60)$ & $49(39.20)$ & $54(43.20)$ & \multirow[t]{3}{*}{0.5934} & Luminal B HER2-pos & $3(17.64)$ & $7(41.18)$ & $7(41.18)$ & \\
\hline $4 \geq 25$ & $6(10.91)$ & $28(50.91)$ & $21(38.18)$ & & Luminal B HER2-neg & $3(13.04)$ & $9(39.13)$ & $11(47.83)$ & \\
\hline Missing & $1(12.50)$ & $3(37.50)$ & $4(50)$ & & HER2-pos & $4(30.77)$ & $5(38.46)$ & $4(30.77)$ & \\
\hline \multicolumn{5}{|c|}{ Estrogen receptor status } & Basal-like & $4(11.43)$ & $12(34.28)$ & $19(54.29)$ & \\
\hline Positive & $20(15.15)$ & $62(46.97)$ & $50(37.88)$ & \multirow[t]{4}{*}{0.4468} & Missing & $1(11.11)$ & $2(22.22)$ & $6(66.67)$ & \\
\hline Negative & 9 (16.98) & $18(33.96)$ & $26(49.06)$ & & \multicolumn{5}{|c|}{ Adapted histological grade } \\
\hline Missing & $0(0)$ & 1 (33.33) & $2(66.67)$ & & I & $6(35.29)$ & $8(47.06)$ & $3(17.65)$ & \multirow[t]{2}{*}{0.0265} \\
\hline \multicolumn{4}{|c|}{ Progesterone receptor status } & & II and III & $23(13.69)$ & $71(42.26)$ & $74(44.05)$ & \\
\hline Positive & $17(15.31)$ & $52(46.85)$ & $42(37.84)$ & \multirow[t]{3}{*}{0.5018} & & & & & \\
\hline Negative & $12(16.67)$ & $26(36.11)$ & $34(47.22)$ & & & & & & \\
\hline Missing & $0(0)$ & $2(40)$ & $3(60)$ & & & & & & \\
\hline
\end{tabular}




\section{DISCUSSION}

TP53 mutations are associated with instability in cell development and cycle progression, and induction of apoptosis in malignant tumors (Hsieh and Lin, 2006). There is a high frequency of TP53 alterations in human cancer. The TP53 gene encodes the p53 protein, which, with its genetic variations, constitutes a complex family of several hundred proteins with heterogeneous properties (Jaiswal et al., 2011).

Our study corroborates the findings of Hsieh and Lin (2006); we did not detect the mutated somatic version of p53 at codons 11 or 248 in BC in Brazilian women. The mutation frequency at codon 248 was 17\% according to Berns et al. (1998), and Powell et al. (2000) reported 10\%. Moreover, Powell et al. (2000) reported that all types of mutation, with the exception of direct DNA contact mutations, are associated with worse survival in women with BC; DNA contact mutations accounted for about $25 \%$ of all mutations and two-thirds of these were in codons 248 and 273 . Although codon 248 is considered a site of gene mutations, we did not find homozygous Gln (GIn/GIn) in Brazilian women with BC. Similarly, the TP53 codon 11 mutation was not evident in this study compared with other studies. In addition, we detected homozygous Glu (Glu/Glu) and homozygous Arg (Arg/Arg) in TP53*11 and TP53*248 polymorphisms, respectively, in all samples.

Genetic variations at TP53 codon 72 in BC have been discussed and studied frequently worldwide. In recent years, gene alterations that lead to a substitution of the amino acid Pro by Arg have been controversial. Consequently, we investigated this single nucleotide polymorphism (SNP) in mammary carcinoma. Proestling et al. (2012) showed that the p53 protein produced by the Arg-encoding allele appears to be a more potent transcription factor and tumor suppressor in vivo in human $\mathrm{BC}$ than the protein produced by the Pro-encoding allele. It has been suggested that the mechanism by which the codon 72 polymorphism increases apoptosis is the enhanced mitochondrial localization of p53 protein in cells with the Arg/Arg genotype; in contrast, the homozygous Pro (Pro/Pro) genotype induces higher levels of G1 arrest compared with the Arg/Arg genotype (Bišof et al., 2012).

Chen et al. (2013) studied Taiwanese women with smaller tumors, and found that there was no difference in genotype distribution between the control and case groups, even though a large number of patients with tumor size TI had the Arg/Arg genotype. Equally importantly, the differences are inherent in the relative prevalence of the polymorphism in different populations; it is interesting to find a discrepancy in the distributions of the TP53 codon 72 polymorphisms between Asian and Caucasian populations. There were more Pro than Arg alleles, and a two-fold higher incidence of the Pro/Pro genotype among the Asian women. However, the Arg/Arg genotype is a risk factor for the development $\mathrm{BC}$ in Caucasian women. A comparison between control and case groups by Huang et al. (2003) revealed a significantly larger risk to Japanese women with the Pro/ Pro genotype, strengthening the idea that racial, ethnic, and environmental differences play a critical role in BC. Moreover, a statistically significant linear correlation between frequency of the allele encoding Pro and latitude has been noted in several populations. This suggests that the two alleles may produce functionally distinct proteins, and that the allele encoding Pro might be selected or influenced according to environmental factors, such as exposure to high levels of ultraviolet light (Dumont et al., 2003). Interestingly, Leu et al. (2013) found that allele frequencies vary with geographic region; the Pro-encoding allele is more common in populations near the equator, while the Arg-encoding allele is more common in those living at a distance from the equator.

Comparative sequence analyses in non-human primates suggest that Pro is the ancestral 
form, although Arg occurs at a high frequency $(>50 \%)$ in some populations. A latitude gradient in variant frequency incited speculation that Pro might protect against the adverse consequences of sunlight or other environmental risk factors attributed to tumor development (Whibley et al., 2009).

Keshava et al. (2002) described the high prevalence of Arg in Caucasian women with BC from New York, although they did not find the same results in African-Americans. Previous studies have focused on European and Arab populations that showed a high incidence of Arg/Arg and the possibility that it represents a risk factor. In Brazil, the Arg/Arg polymorphism is correlated with increased susceptibility to malignant disease, as described by Damin et al. (2006). Contradictory to Damin et al.'s study, we found no such association with the TP53 ${ }^{\star} 72$ polymorphism in Brazilian women, notwithstanding the fact that the Arg/Arg genotype exhibited a prevalence of $42.02 \%$ and the Pro/Pro genotype that of $15.43 \%$ in cancer cases. The equivalent figures in the control group were 41.46 and $16.10 \%$, respectively. The Arg/Arg genotype was predominant in both groups and there was no statistically significant difference between groups $(P=0.9823)$. The allelic frequencies showed that $0.63 \%$ of women without cancer and with $B C$ have at least one Arg allele. To confirm our results, women with BC from Tunisia, Russia, India, Germany, the United Kingdom, Sweden, and Iran were studied and no significant association between the Arg/Arg genotype and the development of a tumor was found; this meta-analysis performed by Ma et al. (2011) revealed no evidence of any association between BC and the codon 72 polymorphism, even when the populations were grouped and submitted to stratified analysis.

$\mathrm{BC}$ is graded based on the scoring of three histologic features: tubule formation, mitotic count, and nuclear pleomorphism. This system is very important and works fairly robustly in classifying grade I and grade III invasive BC, but there is a high degree of variability in classifying grade II tumors (Ping et al., 2014). Our clinical pathological data indicate that only the nuclear grade presented a significant association with the genotype distribution $(P=0.0084)$, and the perceptual grades I, II, and III are described in Table 3. Nuclear grade II was most common and it was most frequently associated with the Pro/Arg genotype. There was a significant association between the Arg allele in the nuclear grades and differentiated pleomorphism and mammary tumors. The Pro/Pro genotype showed lower percentages in grades II and III. Martínez-Arribas et al. (2006) postulated that for women with tumors and pleomorphic cellular nuclei in grade III, there was an important association with poor prognosis parameters.

We also conducted an analysis of adapted histological grade, in which grades II and III were clustered owing to similarity of tissue features and compared with grade I. Comparing the histologic grades, the statistical analysis (Table 3) confirmed a significant association between genotype and cancer progression. Ping et al. (2014) reported that tumor grades showed the most prominent differences in TP53 gene mutation frequency, and also that mutations in this gene were identified in $58 \%$ of grade III invasive breast carcinomas compared with only $4 \%$ in grade I lesions. In addition, there were no statistically significant differences in other variables in this study.

A previous study by Olivier et al. (2006) reported a correlation between TP53 mutations and clinical pathological features, and a significant association with high rates of mortality.

Mostaid et al. (2014) evaluated codon 72 polymorphisms in several cancer types. They suggested that there was a significant relationship between the Pro/Pro genotype in codon 72 and an increased risk of tumorigenesis. Dastjerdi (2011) reported that the Arg/Arg genotype in colorectal cancer showed an association with an increased risk of tumor development in Iran. In contrast, a Brazilian population had a high prevalence of the Arg/Arg genotype and there was no correlation between the polymorphism and the risk of cancer in colorectal carcinoma (Lima et 
al., 2006), which was corroborated by the results for head and neck squamous cell carcinoma (Mojtahedi et al., 2010). Once more, the population profile seems to be an important cause of discrepancies in the association between the polymorphism and the frequency of disease (Eltahir et al., 2012). The data reported in these studies from different regions of the world have convinced us that caution is required when interpreting observations about this polymorphism, bearing in mind the characteristics presented by each studied population.

In summary, our results indicate that polymorphisms at codons 11 and 248 of the TP53 gene do not seem to be associated with predisposition to, and development of, BC in Brazilian women. In contrast, the polymorphism in codon 72 showed possible associations between nuclear grade and adapted histologic grade and BC. However, the allelic and genotypic comparisons of the polymorphism did not reveal statistically significant differences. It may be hypothesized, therefore, that the high prevalence of the Arg/Arg genotype in Brazil may be a regional factor, but may still contribute to the global distribution data and our knowledge of the behavior of BC. Further studies are warranted to elucidate the role of this polymorphism in breast carcinogenesis, and to widen our knowledge of this important disease, which affects millions of women worldwide.

\section{Conflicts of interest}

The authors declare no conflict of interest.

\section{ACKNOWLEDGMENTS}

Research supported by a CNPq grant.

\section{REFERENCES}

Akkiprik M, Sonmez O, Gulluoglu BM, Caglar HB, et al. (2009). Analysis of p53 gene polymorphisms and protein overexpression in patients with breast cancer. Pathol. Oncol. Res. 15: 359-368. http://dx.doi.org/10.1007/s12253-008-9129-6

Berns EM, van Staveren IL, Look MP, Smid M, et al. (1998). Mutations in residues of TP53 that directly contact DNA predict poor outcome in human primary breast cancer. Br. J. Cancer 77: 1130-1136. http://dx.doi.org/10.1038/bjc.1998.187

Bertheau P, Lehmann-Che J, Varna M, Dumay A, et al. (2013). p53 in breast cancer subtypes and new insights into response to chemotherapy. Breast 22 (Suppl 2): S27-S29. http://dx.doi.org/10.1016/j.breast.2013.07.005

Bišof V, Salihović MP, Narančić NS, Skarić-Jurić T, et al. (2012). The TP53 gene polymorphisms and survival of sporadic breast cancer patients. Med. Oncol. 29: 472-478. http://dx.doi.org/10.1007/s12032-011-9875-2

Camargo-Kosugi CM, D’Amora P, Kleine JP, Carvalho CV, et al. (2014). TP53 gene polymorphisms at codons 11, 72, and 248 and association with endometriosis in a Brazilian population. Genet. Mol. Res. 13: 6503-6511. http://dx.doi. org/10.4238/2014.August.26.1

Chen FM, Ou-Yang F, Yang SF, Tsai EM, et al. (2013). P53 codon 72 polymorphism in Taiwanese breast cancer patients. Kaohsiung J. Med. Sci. 29: 259-264. http://dx.doi.org/10.1016/j.kjms.2012.09.004

Damin AP, Frazzon AP, Damin DC, Roehe A, et al. (2006). Evidence for an association of TP53 codon 72 polymorphism with breast cancer risk. Cancer Detect. Prev. 30: 523-529. http://dx.doi.org/10.1016/j.cdp.2006.09.007

Dastjerdi MN (2011). TP53 codon 72 polymorphism and P53 protein expression in colorectal cancer specimens in Isfahan. Acta Med. Iran. 49: 71-77.

de Moura Gallo CV, Azevedo E Silva Mendonça G, de Moraes E, Olivier M, et al. (2005). TP53 mutations as biomarkers for cancer epidemiology in Latin America: current knowledge and perspectives. Mutat. Res. 589: 192-207. http://dx.doi. org/10.1016/j.mrrev.2005.01.002

Dumont P, Leu JI, Della Pietra AC, 3rd, George DL, et al. (2003). The codon 72 polymorphic variants of p53 have markedly different apoptotic potential. Nat. Genet. 33: 357-365. http://dx.doi.org/10.1038/ng1093

Eltahir HA, Adam AA, Yahia ZA, Ali NF, et al. (2012). p53 Codon 72 arginine/proline polymorphism and cancer in Sudan. Mol. Biol. Rep. 39: 10833-10836. http://dx.doi.org/10.1007/s11033-012-1978-0 
Guimaraes DP and Hainaut P (2002). TP53: a key gene in human cancer. Biochimie 84: 83-93. http://dx.doi.org/10.1016/ $\underline{\text { S0300-9084(01)01356-6 }}$

Hsieh YY and Lin CS (2006). P53 codon 11, 72, and 248 gene polymorphisms in endometriosis. Int. J. Biol. Sci. 2: 188-193. http://dx.doi.org/10.7150/ijbs.2.188

Huang XE, Hamajima N, Katsuda N, Matsuo K, et al. (2003). Association of p53 codon Arg72Pro and p73 G4C14-to-A4T14 at exon 2 genetic polymorphisms with the risk of Japanese breast cancer. Breast Cancer 10: 307-311. http://dx.doi. org/10.1007/BF02967650

Jaiswal PK, Goel A and Mittal RD (2011). Association of p53 codon 248 (exon7) with urinary bladder cancer risk in the North Indian population. Biosci. Trends 5: 205-210. http://dx.doi.org/10.5582/bst.2011.v5.5.205

Keshava C, Frye BL, Wolff MS, McCanlies EC, et al. (2002). Waf-1 (p21) and p53 polymorphisms in breast cancer. Cancer Epidemiol. Biomarkers Prev. 11: 127-130.

Leu JI, Murphy ME and George DL (2013). The p53 codon 72 polymorphism modifies the cellular response to inflammatory challenge in the liver. J. Liver 2: 117.

Levine AJ and Oren M (2009). The first 30 years of p53: growing ever more complex. Nat. Rev. Cancer 9: 749-758. http:// dx.doi.org/10.1038/nrc2723

Lima JM, Serafim PV, Silva ID and Forones NM (2006). [Role of the genetic polymorphism of p53 (codon 72) gene in colorectal cancer]. Arq. Gastroenterol. 43: 8-13. http://dx.doi.org/10.1590/S0004-28032006000100005

Ma Y, Yang J, Liu Z, Zhang P, et al. (2011). No significant association between the TP53 codon 72 polymorphism and breast cancer risk: a meta-analysis of 21 studies involving 24,063 subjects. Breast Cancer Res. Treat. 125: 201-205. http:// dx.doi.org/10.1007/s10549-010-0920-1

Martínez-Arribas F, Martín-Garabato E, Lafuente P, Tejerina A, et al. (2006). Proliferation measurement in breast cancer by two different methods. Anticancer Res. 26 (1A): 199-202.

Méplan C, Richard MJ and Hainaut P (2000). Metalloregulation of the tumor suppressor protein p53: zinc mediates the renaturation of p53 after exposure to metal chelators in vitro and in intact cells. Oncogene 19: 5227-5236. http://dx.doi. org/10.1038/sj.onc.1203907

Mojtahedi Z, Hashemi SB, Khademi B, Karimi M, et al. (2010). p53 codon 72 polymorphism association with head and neck squamous cell carcinoma. Rev. Bras. Otorrinolaringol. (Engl. Ed) 76: 316-320.

Mostaid MS, Ahmed MU, Islam MS, Bin Sayeed MS, et al. (2014). Lung cancer risk in relation to TP53 codon 47 and codon 72 polymorphism in Bangladeshi population. Tumour Biol. 35: 10309-10317. http://dx.doi.org/10.1007/s13277-014-2285-2

Olivier M, Langerød A, Carrieri P, Bergh J, et al. (2006). The clinical value of somatic TP53 gene mutations in 1,794 patients with breast cancer. Clin. Cancer Res. 12: 1157-1167. http://dx.doi.org/10.1158/1078-0432.CCR-05-1029

Pim D and Banks L (2004). p53 polymorphic variants at codon 72 exert different effects on cell cycle progression. Int. J. Cancer 108: 196-199. http://dx.doi.org/10.1002/ijc.11548

Ping Z, Siegal GP, Almeida JS, Schnitt SJ, et al. (2014). Mining genome sequencing data to identify the genomic features linked to breast cancer histopathology. J. Pathol. Inform. 5: 3. http://dx.doi.org/10.4103/2153-3539.126147

Powell B, Soong R, lacopetta B, Seshadri R, et al. (2000). Prognostic significance of mutations to different structural and functional regions of the p53 gene in breast cancer. Clin. Cancer Res. 6: 443-451.

Proestling K, Hebar A, Pruckner N, Marton E, et al. (2012). The Pro allele of the p53 codon 72 polymorphism is associated with decreased intratumoral expression of BAX and p21, and increased breast cancer risk. PLoS One 7: e47325. http://dx.doi. org/10.1371/journal.pone.0047325

Stojnev S, Golubović M and Babović P (2010). TP53 gene mutations - from guardian of the genome to oncogene. Acta Medica Medianae 49: 59-63.

Whibley C, Pharoah PD and Hollstein M (2009). p53 polymorphisms: cancer implications. Nat. Rev. Cancer 9: 95-107. http:// dx.doi.org/10.1038/nrc2584

Yersal O and Barutca S (2014). Biological subtypes of breast cancer: Prognostic and therapeutic implications. World J. Clin. Oncol. 5: 412-424. http://dx.doi.org/10.5306/wjco.v5.i3.412 